\title{
Exploring the Significance of Context in Meaning: Speech Act Features of Performative Political- Speeches of President Umaru Musa Yar'Adua
}

\author{
By Susan Akinkurolere*
}

\begin{abstract}
Political speeches, no doubt, have been object and subject of diverse linguistic and nonlinguistic analyses for decades. Apparently, communication is the most vital tool in politicking within and outside Nigeria as politicians vehemently trade in various discourses and arguments through fliers, pamphlets, manifestoes, public statements and speeches. In fact, political speeches are occasioned by different contexts or situations. Hence, the research portrays context as an integral part in speaker's intention and hearer's interpretation. Specifically, performative political-speeches are selected to explore the significance of the context in negotiating pragmatic meaning through the frame work of Speech Act Theory. The data are drawn from two speeches of Nigerian President Umaru Musa Yar'Adua based on periodisation (2008-2009). The Speech Act analysis of these action political discourses provides the understanding that political leaders employ unique speech act types which are mainly assertive when delivering performative political speeches. The reason for this is premised on the fact that the speeches are performative and delivered by a President in a democratic government. The study, therefore, recommends a contrastive analysis of performative and ceremonial political speeches of the President or other political leaders to further demonstrate the influence of context on speech act patterns.
\end{abstract}

\section{Introduction}

Communication involves an exchange of information or message among participants. Among human beings, the most expedient tool of communication is language. No wonder, language of communication is as important as the message itself, albeit, there are other means of communication, which include silence, body language, signs, paralanguage, facial expression etc. The choice of words in language determines interpretation or meaning. Scholars in the fields of Pragmatics and Stylistics, have studied such choices in language through distinct approaches. No doubt, choice of words, as style, is within the ambit of Stylistics, while Pragmatics is concerned about intended and interpreted meaning through words.

According to Nouraldeen, "Meaning is the cornerstone of language, since people communicate principally to convey meaning. Meaning is more than a definition in a dictionary; it is also found in a context. Meaning and context are interdependent, i.e., meaning cannot be communicated without context, and

*Senior Lecturer, Kampala International University, Uganda. 
context cannot be established without meaning."1 In essence, distinct features or patterns of features, in communication, are not just significant for meaning but related to the context of use. It is along this reasoning that Mahmud, cited in Akinkurolere's work, argues that:

Language varies not only according to social characteristics of the speaker, but also according to the social context in which he finds himself...The same speaker uses language for different situations and for different purposes. ${ }^{2}$

The quoted portion emphasises that variation in language use is not only stylistically significant but pragmatically relevant. In essence, the context, in which a language is employed, goes a long way to determine the formal and the substantial features of the language. It is along this reasoning that Bloor and Bloor observe that "when people use language to make meanings, they do so in specific situations, and the form of the language that they use in discourse is influenced by the complex aspects of those situations." ${ }^{3}$

In consonance with the above, Halliday, ${ }^{4}$ in his discussion of the textual function of language, submits that language provides for making links with itself and with features of the situation in which it is used. He went further to emphasize that the textual function of language enables the speaker or writer to construct texts or connected passages of discourse that are situationally relevant. Hence, the use of language in a particular situation may be quite different from another situation.

The context is simply the situation of language use. In essence, the cognitive constructs, comprising those components of the situation that are recognized as relevant to the understanding and creation of meaning by the human agent, culminate into what is known as context. ${ }^{5}$ Also, on context, Lyons posits thus:

A theoretical construct in the postulation of which the linguist abstracts from the actual situation and establishes as contextual all the factors which, by virtue of their influence upon the participants in the language event, systematically

1. Abdullah Nouraldeen, "Meaning and Context-Three Different Perspectives," British Journal of English Linguistics 3, no. 2 (2015): 13-17.

2. Susan Akinkurolere, "A Speech Act Analysis of Selected Political Speeches of President Umaru Musa Yar'Adua" (Unpublished MA dissertation, Obafemi Awolowo University, 2011); Olayemi Mahmud, "A Stylistic Study of the Language of Television Advertisement in Nigeria" (Unpublished MA dissertation, Adekunle Ajasin University, 2004).

3. Thomas Bloor and Meriel Bloor, The Functional Analysis of English: A Hallidayan Approach (London: Arnold, 2004).

4. Micheal Halliday, "Language Structure and Language Function," in New Horizons in Linguistics, ed. John Lyons (USA: Penguin Books, 1970), 142-165.

5. Eva Illes, "The Definition of Context and its Implications for Language Teaching" (Doctoral dissertation-PhD, Institute of Education, University of London, 2001). 
determine the form and the appropriateness of the meaning of utterances. ${ }^{6}$

In a speech event, there are physical, socio-cultural, linguistic or epistemic context. Deductions or interpretations in analysis are based on the context. To pragmatists, the context is quite germane in interpretation. In fact, recent studies in Stylistics ${ }^{7}$ employed a paradigm shift from pure stylistic approach to pragma-stylistics. This development allows the significance of context to be investigated when considering stylistic features as pragmatic notion. Context is a pragmatic concept that differentiates it from other sub-linguistic fields. Illes gives a rather insightful perspective on context thus:

In any case, it is this meaning (that) the sentence obtains when it becomes an utterance in relation to a context that forms the concern of pragmatics. Since context is a feature that generally distinguishes pragmatics from semantics, definitions of pragmatics are frequently formulated in reference to it. Pragmatics has thus been seen as the inquiry into the contribution context makes to meaning, ${ }^{8}$ or the examination of contextual and speaker meaning. ${ }^{9}$

Politics is a broad field and subject of discourses. Political discourses have been widely researched into by various scholars and Akinkurolere opines that "aspects of political communication include, but are not limited to, statements made by politicians, writings of politicians, political speeches, election campaign, political broadcast, parliamentary debates and political interviews." ${ }^{10}$ Indeed, these are basically meant to inform and instruct people in line with their political leaders intentions. Particularly, speech making is an activity in politics that depends of language resource. Opeibi appropriately justifies this by stating that:

No matter how good a candidate's manifesto is; no matter how superior political thoughts and ideologies of a political party may be, these can only be expressed and further translated into social actions for social change and social continuity

6. John Lyons, Semantics (Volume 2) (Cambridge: Cambridge University Press, 1977).

7. Abiodun Awolaja, "A Pragmastylistic Analysis of Helon Habila's Waiting for an Angel and Measurement Time" (Unpublished MA dissertation, Obafemi Awolowo University, 2012); John Abuya, "A Pragma-stylistic Analysis of Inaugural Speech of President Goodluck Ebele Jonathan's Inaugural Speech," English Language Teaching 5, no. 11 (2012): 8-15; Susan Akinkurolere, "A Pragmastylistic Analysis of Chinua Achebe's Arrow of God," Humanities and Social Sciences Review 3, no. 3 (2014): 363-370; Susan Akinkurolere, "A Lexico-pragmatic Analysis of Inaugural Speeches of Speakers of State Houses of Assembly in Nigeria" (Unpublished PhD dissertation, Obafemi Awolowo University, 2016).

8. George Yule, Pragmatics (Oxford: Oxford University Press, 1996).

9. Illes, "The Definition of Context and its Implications for Language Teaching. 10. Akinkurolere, "A Lexico-pragmatic Analysis of Inaugural Speeches. 
through the facilities provided by language. ${ }^{11}$

The study, therefore, attempts to explore the significance of context on meaning making by identifying the speech act features of the selected speeches; analyse the identified features to reflect their implications on meaning making; and demonstrate speech acts' patterns in the context of politics. It is imperative to review pragmatics and speech act theory. This provides a background with a view to understanding the linguistic approach and framework adopted, analysis of data, discussion of results and conclusion based on the performative speeches of President Umaru Musa Yar'Adua.

\section{Research Question}

The research questions for the paper are stated as follows:

i. What are the predominant speech acts in the selected speeches?

ii. What are the implications of the identified speech acts on meaning making?

iii. How does context of politics influence or determine the analysed speech act features?

\section{Pragmatics and Speech Act Theory}

The linguistic approach for the research is Pragmatics through Speech Act Theory. Pragmatics is one of the major fields in Linguistics that could unravel meaning in language use, as an offshoot of Discourse Analysis, since the meaning of a discourse depends on context for an appropriate interpretation. ${ }^{12} \mathrm{~A}$ discourse is a linguistic unit larger than a sentence, which could either be in spoken or written form, although language is primarily speech. Discourse Analysis studies the organization of language larger than sentence. Akinkurolere avers thus:

Pragmatics is characterized by the fact that it deals with natural discourse whether spoken or written. Pragmatics deals extensively with various extra linguistic features that influence or affect the meaning of a discourse. Thus, it provides natural discourse with empirical investigation..$^{13}$

Morris avers that Pragmatics is the study of the relations between signs and

11. Babatunde Opeibi, Discourse, Politics and the 1993 Presidential Election Campaigns in Nigeria (Lagos: Nouvelle Communications Limited, 2009).

12. Akinkurolere, "A Speech Act Analysis of Selected Political Speeches.

13. Akinkurolere, "A Lexico-pragmatic Analysis of Inaugural Speeches. 
their interpreters. ${ }^{14}$ This sign represents any linguistic item. With further development, So also, Thomas claims that the most common definitions of Pragmatics are "meaning in use" and "meaning in context."15

Pragmatics deals with appropriateness of linguistic choice to the context, and this covers the speaker's intended meaning. ${ }^{16}$ It is the need for appropriateness that makes a speaker or writer choose a particular linguistic code among several other options that are available for use in a discourse. While, Loukusa opines that Pragmatics is defined as the study of language in context, and specifically how context affects the interpretation of utterances. ${ }^{17}$ These various definitions of Pragmatics pay critical attention to the significance and relevance of context in the conveyance of intended meaning. Hence, pragmatic analysts investigate the relationship between language use and language user in situational contexts.

Actions that are performed when words are employed is called Speech act. The Speech Acts theory is regarded as "How to Do Things with Words Theory" since it has its roots in the work of Austin ${ }^{18}$ and Searle. ${ }^{19}$ They are able to provide a shift from constative notion to performative notion in the empirical verifiability of signs; that is, the truthfulness of signs to what an expression does when it is uttered. Indeed, the distinctive recognition of performative speech can be traced to Austin's opinion that an action is performed through a speech. ${ }^{20}$ According to Akinkurolere, Austin distinguished explicit performative from implicit performative. Explicit performative is a statement which does not contain an expression of the act while implicit performative statement contains an expression of the act. ${ }^{21}$

Speech acts according to Austin fall into three aspects, which are locutionary, illocutionary and perlocutionary act. A locutionary act is an act of saying something; that is, the act of producing an utterance. On utterance, Austin explains that it is "the utterance of certain noises, the utterances of certain words and construction, and the utterances are with certain 'meaning' in the favourite

14. Charles Morris, Foundations of the Theory of Signs (Chicago: University of Chicago Press, 1938).

15. Jenny Thomas, Meaning in Interaction: An Introduction to Pragmatics (New York: Longman, 1995).

16. George Yule, The Study of Language (Cambridge: Cambridge University Press, 1985).

17. Soile Loukasa, "The Use of Context in Pragmatic Language Comprehension in Normally Developing Children and Children with Asperger Syndrome/High-Functioning Autism: An Application of Relevance Theory" (University dissertation, Faculty of Humanities, University of Oulu, 2007).

18. Ibid.

19. John Austin, How to Do Things with Words (Oxford: Oxford University Press, 1962).

20. Loukasa, "The Use of Context in Pragmatic Language Comprehension.

21. Akinkurolere, "A Speech Act Analysis of Selected Political Speeches. 
philosophical sense and a certain 'reference'."22 The illocutionary act is the social act performed by the speaker: making a promise or statement, commanding or requesting, asking a question, etc. ${ }^{23}$ While, Adeyanju describes perlocutionary act as the intended or unintended consequences of the speaker's utterance. ${ }^{24}$

There was an improvement on Speech Act theory, which distinguishes between two types of speech acts: direct and indirect speech acts. The direct speech act expresses an act in a direct manner such that an example: "The driver said, 'stand up' is a command or request for an action. But a statement like 'shall we rise up' is syntactically a question but functionally a request for an action, therefore, it is an indirect request speech act. That is, an utterance which expresses an action in an indirect manner." Searle classified illocutionary acts into five speech acts categories as explained and used by Mey ${ }^{25}$ thus:

I. Representatives (or assertives): These speech acts are assertions about a state of affairs in the world. It could also be regarded to as assertions, facts, positions, conclusions that are made on situations.

II. Directives: As the name implies, these speech acts embody an effort on the part of the speaker to get the hearer to do something, to "direct" him or her towards some goal (of the speaker's mostly). The directive act covers requesting, commanding, and ordering the hearer to perform certain tasks.

III. Commissives: Like directives, commissives operate a change in the world by means of creating an obligation; however, this obligation is created in the speaker, not in the hearer, as in the case of the directives. These include promising, pledging one's support, loyalty or allegiance and vowing.

IV. Expressives: This speech act, as the word says, expresses an inner state of the speaker; the expression is essentially subjective and tells us nothing about the world. Expressives basically center on what goes on in the mind of the speaker; that is, the inner workings of the mind which include feeling, thinking, congratulating, praising, wishing.

V. Declaratives: Declaratives bring about some alteration in the status or condition of the referred object or objects solely by virtue of the fact that the declaration has been successfully performed.

Also, Bach and Hanish ${ }^{26}$ provide further classification of speech acts. They further classify communicative illocutionary acts into four categories namely: constatives, directives, commissives, acknowledgements, and conventional illocutionary into effectives and verdictives. Communicative illocutionary acts can be classified into the following:

22. Loukasa, "The Use of Context in Pragmatic Language Comprehension.

23. Akinkurolere, "A Speech Act Analysis of Selected Political Speeches.

24. Dele Adeyanju, "Pragmatic Features of Political Speeches in English by Some Prominent Nigerian Leaders," Journal of Political Discourse Analysis 2, no. 2 (2009): 173-190.

25. Jacob Mey, Pragmatics: An Introduction (Oxford: Blackwell Publishing, 2006).

26. Kent Bach and Robert Harnish, Linguistic Communication and Speech Acts (Cambridge: M.I.T Press, 1979). 
I. Constatives: These are acts that express a speaker's belief and his desire that the hearer forms a similar one.

II. Directives: They express some attitude about a possible future action by the hearer and the intention that his utterance be taken as reason for the hearer's action.

III. Commissives: The acts express the speaker's intention to do something and the belief that his utterance obliges him to do it.

IV. Acknowledgments: They express feelings toward the hearer (or the intention that the utterance will meet some social expectations regarding the expression of feelings).

While the conventional illocutionary acts can be classified into two categories:

I. Effectives: When these acts are produced by the appropriate person in appropriate circumstances produce a change or a new fact in an institutional context.

II. Verdictives: These acts do not produce facts, but determine facts, natural or institutional, with an official, binding effect in the institutional context.

Felicity conditions have to be satisfied before a speech act could be successful. In a nutshell, felicity conditions refer to contextual conditions necessary for the success of a speech act. ${ }^{27}$ By this, speech acts of sentences in the data were identified and related to the context in which they were presented.

\section{Methodology}

The research was based on speech act analysis of two selected speeches of Umaru Musa Yar'Adua captioned as Text A and Text B. Text A is Swearing-in of New Ministers speech while Text B is Budget speech. These speeches were presented during major events in his short tenure. Speeches were also periodised from 2008 to 2009 as follows: The Swearing-in Ceremony of New Ministers Speech (2008) and Budget Speech (2009). These were selected with a view to subjecting them to thorough analysis. The speeches were got from the Internet and analysed for speech act features. The linguistic framework of Speech Act theory of Searle ${ }^{28}$ and Bach and Harnish ${ }^{29}$ was applied to the study as earlier stated in the paper.

The selected speeches vary in length and number of sentences. Therefore, equal portions were extracted from the speeches. All the sentences (16 sentences) in Swearing-in Ceremony speech were analysed while the same number of sentences were selected in Budget speech making a total of thirtytwo sentences Thus, in each of the speeches, 16 sentences were selected. The extracted sentences in each speech were numbered, therefore we have A1-16 and B1-16. The analysis, at the levels of locution, illocution and perlocution,

27. Ibid.

28. John Searle, Speech Acts (Cambridge: Cambridge University Press, 1969).

29. Bach and Harnish, Linguistic Communication and Speech Acts. 
was presented while the frequency and percentage tables were used to show the analysis of the sentences extracted from the speeches. This was done in order to make the analysis clear and easy to understand. Moreover, Sentences A1-A8 and B1-B8 were the first ten sentences extracted from the speeches, while Sentences A9-16 and B9-16 were the last ten sentences of the speeches. The introductory and the concluding parts of a speech are crucial in the delivery and identification of intended messages or acts of the speaker. This was the reason sixteen sentences were extracted from the Budget Speech.

Efforts were made to calculate the frequencies and percentages of the speech acts types so as to make interpretation of the tables clear and empirical. The choice of Speech Act theory was considered appropriate for the analysis as the theory served as the spread sheet for the analysis and evaluation of the selected speeches. Discussion and conclusion were based on the comprehensive results of the analysis as shown in frequency and percentage tables.

\section{Analysis of the Data}

Each sentence was presented before the identification of speech acts. This was done at the levels of locution, illocutionary and perlocutionary levels. Tables were drawn to reflect the frequency and percentage in each speech. A final table was also drawn to show the summary of frequencies and percentages of the speeches. The calculation of the percentages of the speech acts in a speech was based on the number of sentences and not on the total number of speech acts in each speech. Thus we have:

Total number of speech acts

Total number of sentences in a speech

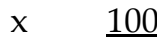

This served as the basis for our discussion in this study.

\section{A Speech Act Analysis of the Swearing-in of New Ministers (A)}

\section{Introduction}

In 2008, President Umaru Musa Yar'Adua appointed some ministers into various portfolios. On this occasion, he gave an address. The occasion was significant and the speech too, as it portrayed the speech of the President at the moment he officially inaugurated members of the Federal Executive Council.

\section{Analysis}

\section{Sentence A1}

Locution: Nineteen months into the life of our Administration, it is with a deep sense of appreciation that I welcome on board the newly sworn-in members 
of the Federal Executive Council this morning.

Illocutionary Act:

(a) Direct: assertive (stating)

(a) Indirect: verdictive (assessing)

Expected Perlocutionary Effect: elation

\section{Sentence A2}

Locution: In the same breath, I welcome the old Executive Council members to a new dispensation - one which establishes definite performance benchmarks, and insists on effective service delivery, strict adherence to the policy objectives of this administration as encapsulated in the Seven-Point Agenda.

Illocutionary Act:

(a) Direct: assertive (stating)

(b) Indirect: declarative (confirming)

Expected Perlocutionary Effect: cheerfulness

\section{Sentence A3}

Locution: These are minimal standards that will guarantee continued membership of the Executive Council.

Illocutionary Act:

(a) Direct: assertive (stating)

(b) Indirect: declarative (confirming)

Expected Perlocutionary Effect: hopefulness

\section{Sentence A4}

Locution: While congratulating you all, I would like to admonish that you see your appointment at all times is not an opportunity for self aggrandizement or the pursuit of narrow, selfish interests.

Illocutionary Act:

(a) Direct: assertive (stating)

(b) Indirect: directive (admonishing)

Expected Perlocutionary Effect: reflective

\section{Sentence A5}

Locution: The task before the nation calls for honesty of purpose, sincerity, consummate diligence, and unmediated commitment to the national demand no 
less from each and every one of us.

Illocutionary Act:

(a) Direct: assertive (stating)

(b) Indirect: directive (appealing)

Expected Perlocutionary Effect: patriotism

\section{Sentence A6}

Locution: The people of this nation demand no less from each and every one of us.

Illocutionary Act:

(a) Direct: assertive (saying)

(b) Indirect: directive (admonishing)

Expected Perlocutionary Effect: cooperation

\section{Sentence A7}

Locution: Our every act must be guided by the highest standards of integrity and the fear of God.

Illocutionary Act:

(a) Direct: directive (compelling)

(b) Indirect: declarative (admonishing)

Expected Perlocutionary Effect: compliance

\section{Sentence A8}

Locution: I must reiterate our Administration's total abhorrence of corruption in all its ramifications and our insistence on absolute compliance with established rules, regulations and procedures in the conduct of all government business.

Illocutionary Act:

(a) Direct: declarative (insisting)

(b) Indirect: assertive (stating)

Expected Perlocutionary Effect: compliance

\section{Sentence A9}

Locution: Any proven case of corrupt practices or non-conformity with the rule of law and constitutionality will be visited with the strictest sanctions.

Illocutionary Act: 
(a) Direct: verdictive (asserting)

(b) Indirect: declarative (insisting)

Expected Perlocutionary Effect: caution

Sentence A10

Locution: In this period of stark economic realities at home and unprecedented global economic challenges, we all must begin to think out of the box, recommit to the ideal of prudent and judicious application of resources, and stay faithful to the principles of value for money, transparency, accountability and the rule of law.

Illocutionary Act:

(a) Direct: declarative (insisting)

(b) Indirect: assertive (stating)

Expected Perlocutionary Effect: compliance

Sentence A11

Locution: As you honestly and diligently discharge your respective duties as Honorable Ministers of the Federal Republic of Nigeria, be assured of my full confidence, unstinting support, and guidance at all times.

Illocutionary Act:

(a) Direct: assertive (stating)

(b) Indirect: commisive (assuring)

Expected Perlocutionary Effect: cheerfulness

Sentence A12

Locution: In the days ahead, you shall get mandate which each of you will be expected to meet as dictated by your portfolio.

Illocutionary Act:

(a) Direct: assertive (stating)

(b) Indirect: commisive (promising)

Expected Perlocutionary Effect: commitment

Sentence A13

Locution: Ultimately, I expect that this Council will function as a compact, effective, efficient, and focused team in the repositioning and transformation of our nation.

Illocutionary Act: 
(a) Direct: assertive (stating)

(b) Indirect: directive (requesting)

Expected Perlocutionary Effect: motivation

Sentence A14

Locution: Distinguished Ladies and Gentlemen, once again, I congratulate you all and wish you every success and productive service to our fatherland.

Illocutionary Act:

(a) Direct: assertive (stating)

(b) Indirect: expressive (greetings)

Expected Perlocutionary Effect: nationalism

Sentence A15

Locution: May Almighty God bless you all and continue to bless our dear nation.

Illocutionary Act:

(a) Direct: assertive (stating)

(b) Indirect: directive (requesting)

Expected Perlocutionary Effect: patriotism

Sentence A16

Locution: Thank you.

Illocutionary Act:

(a) Direct: expressive(appreciating)

(b) Indirect: assertive (saying)

Expected Perlocutionary Effect: applause

\section{A Speech Act Analysis of Budget Speech (B)}

\section{Introduction}

The 2009 budget speech was presented before the members of National Assembly for ratification and approval. The speech was significant considering the fact that it bordered on the finance of the country and at a period when there was a global financial recession. The speech was presented by the President in order to seek the approval of the legislative arm of the government. 


\section{Analysis}

\section{Sentence B1}

Locution: It is a pleasure for me to present the 2009 Budget to the National Assembly today, as we move to reposition our economy to meet the challenges and take advantage of the opportunities that we are faced with at home and internationally.

Illocutionary Act:

(a) Direct: assertive (saying)

(b) Indirect: commissive (promising)

Expected Perlocutionary Effect: support

\section{Sentence B2}

Locution: The changing international oil market poses grave concerns for our fiscal outlook.

Illocutionary Act:

(a) Direct: assertive (stating)

(b) Indirect: verdictive (assessing)

Expected Perlocutionary Effect: understanding

\section{Sentence B3}

Locution: The global financial crisis has led to slowing growth across the world's economies, resulting in a lower demand for commodities, especially oil.

Illocutionary Act:

(a) Direct: assertive (stating)

(b) Indirect: verdictive (assessing)

Expected Perlocutionary Effect: reflection

\section{Sentence B4}

Locution: While speculative investment activities had helped to buoy oil prices in recent months, the reality of global recession is beginning to be fully appreciated across the globe, and more poignantly in Nigeria by its adverse impact on the international price of oil. 
Illocutionary Act:

(a) Direct: assertive (stating)

(b) Indirect: verdictive (assessing)

Expected Perlocutionary Effect: acceptance

Sentence B5

Locution: The recent volatility of the oil price is apparent in the unprecedented decline of prices from record highs of about US\$147/barrel in July this year to current prices of about US\$50/barrel, and there is no guarantee that prices will not further decline despite OPEC's recent mitigating efforts.

Illocutionary Act:

(a) Direct: assertive (stating)

(b) Indirect: declarative (admonitory)

Expected Perlocutionary Effect: sobriety

\section{Sentence B6}

Locution: We therefore must adopt a prudent outlook that does not invest misplaced confidence in the expectation of unrealistically high prices.

Illocutionary Act:

(a) Direct: declarative

(b) Indirect: commissive

Expected Perlocutionary Effect: hopefulness

\section{Sentence B7}

Locution: Notwithstanding the global downturn, Nigeria's economic growth remains on track, buoyed by the strong performance of the non-oil sector.

Illocutionary Act:

(a) Direct: assertive (stating)

(b) Indirect: declarative (confirming)

Expected Perlocutionary Effect: optimism

\section{Sentence B8}

Locution Growth in the non-oil sector, particularly in agriculture, remains robust, at an estimated $9 \%$.

Illocutionary Act: 
(a) Direct: assertive (stating)

(b) Indirect: declarative (confirming)

Expected Perlocutionary Effect: hopefulness

Sentence B9

Locution: We remain steadfastly focused on our vision for Nigeria, as encapsulated in the Seven-Point Agenda and the Vision 20-2020.

Illocutionary Act:

(a) Direct: commissive (assuring)

(b) Indirect: declarative (confirming)

Expected Perlocutionary Effect: motivation

Sentence B10

Locution: By being faithful to our guiding principles of value for money, service delivery, accountability and the rule of law, we can face the challenges thrown up by the uncertainty and turbulence currently confronting the global economy with a well-founded confidence in the prudence of our policies and our unwavering resolve to see them through.

Illocutionary Act:

(a) Direct: directive (admonishing)

(b) Indirect: assertive (stating)

Expected Perlocutionary Effect: commitment

\section{Sentence B11}

Locution: We will actively engage with the Legislature with a view to ensuring that not only will the 2009 Budget be faithfully implemented but also that our success in this undertaking will lay a firm foundation for future budget cycles.

Illocutionary Act:

(a) Direct: commissive (promising)

(b) Indirect: assertive (saying)

Expected Perlocutionary Effect: hopefulness

Sentence B12

Locution: Respected Members of the National Assembly, I once again wish to thank you for your patriotism, cooperative spirit, and steady support over the course of the annual budget cycle.

Illocutionary Act: 
(a) Direct: expressive (appreciating)

(b) Indirect: assertive (saying)

Expected Perlocutionary Effect: continual loyalty

Sentence B13

Locution: I must place on record the consummate and thorough manner in which the National Assembly has engaged with the Executive in our budget preparation, monitoring and implementation work.

Illocutionary Act:

(a) Direct: assertive (stating)

(b) Indirect: expressive (commending)

Expected Perlocutionary Effect: continual support

\section{Sentence B14}

Locution: As I lay before you the 2009 Budget Proposal of the Federal Government of Nigeria for your consideration, I look forward to an expeditious passage, and even greater collaborative efforts in our joint effort to move our great nation forward into a more promising future.

Illocutionary Act:

(a) Direct: assertive (stating)

(b) Indirect: directive (requesting)

Expected Perlocutionary Effect: cooperation

Sentence B15

Locution: I thank you most sincerely for your attention.

Illocutionary Act:

(a) Direct: expressive (appreciating)

(b) Indirect: assertive (stating)

Expected Perlocutionary Effect: approval

\section{Sentence B16}

Locution: May God bless the Federal Republic of Nigeria.

Illocutionary Act:

(a) Direct: assertive (stating)

(b) Indirect: directive (requesting)

Expected Perlocutionary Effect: contentment 


\section{Discussion of the Results}

Language, indeed, is a powerful weapon in getting to the political thoughts and ideologies of politicians; hence, the language use of Yar'Adua in performative-political speeches was analysed through two selected speeches in order to portray his thought in a particular context. The Speech Act theory was applied to the study of the speeches and it was discovered that the five categories of Searle's speech acts ${ }^{30}$ manifested with verdictives category from Bach and Harnish ${ }^{31}$ were prominent in the speeches.

Most of the sentences in the Swearing-in Ceremony of New Ministers speech were assertive at $87.5 \%$, and this is to say that most direct illocutionary acts of all the sentences in the extracted portion of the speech were assertive, while $37.5 \%$ of the sentences were declarative; these were employed by President to give the new ministers instructions and guidelines that would guide them in their different offices. In essence, the directive acts were used to inform and instruct the new ministers on what he expected from them (Table 1).

Table 1. Analysis Text A (Swearing-in Ceremony of Ministers Speech)

\begin{tabular}{|l|c|c|}
\hline Speech Acts (Direct and Indirect) & Frequencies & Percentages \\
\hline Assertives & 14 & $87.5 \%$ \\
\hline Directives & 6 & $37.5 \%$ \\
\hline Expressives & 2 & $12.5 \%$ \\
\hline Verdictives & 2 & $12.5 \%$ \\
\hline Commisives & 2 & $12.5 \%$ \\
\hline Declaratives & 6 & $37.5 \%$ \\
\hline
\end{tabular}

Total No of Acts:

32

In the Budget Speech, the sentences were $87.5 \%$ assertive, the President had prepared the Budget by stating the amount needed to run the fiscal year. The speech was characterized by sentences that were verdictives $(18.8 \%)$, declaratives (31\%), directives $(18.8 \%)$, expressives $(18.8 \%)$ and commisives $(25 \%)$. The president performed the declarative speech acts in the process of assessing the financial situation of the country - Nigeria, while other speech acts were performed when he was appealing to the legislators for the approval of the budget, their support and cooperation. Through the commissive acts, they were assured of the executive's cooperation and unalloyed support to provide a better economy for the nation, despite unfavorable circumstances (Table 2).

30. Searle, Speech Acts.

31. Bach and Harnish, Linguistic Communication and Speech Acts. 
Table 2. Analysis Text B (Budget Speech)

\begin{tabular}{|l|c|c|}
\hline Speech Acts (Direct and Indirect) & Frequencies & Percentages \\
\hline Assertives & 14 & $87.5 \%$ \\
\hline Directives & 3 & $18.8 \%$ \\
\hline Expressives & 3 & $18.8 \%$ \\
\hline Verdictives & 3 & $18.8 \%$ \\
\hline Commisives & 4 & $25 \%$ \\
\hline Declaratives & 5 & $31 \%$ \\
\hline
\end{tabular}

Total No of Acts:

32

From the tables' results, it was realised that each of the sentences analysed comprised both direct illocutionary and indirect acts as demonstrated through the analysis. This showed that the President did more than saying or stating, in the process of making statements, various other speech acts were performed. The fact that all the sentences have both direct and indirect speech acts brought the total number of the illocutionary acts to sixty four, as derived from thirty two sentences. The indirect acts were mainly in the categories of directives, verdictives, commisives, expressives and declaratives.

In a global macro-speech act sense, the totality of the speeches selected and analysed in our data displayed efforts made by President Yar' Adua to exercise his authority in an acceptable and appealing manner. It was discovered from the overall relative frequency percentages (ORFPs) that the President had used mainly sentences that were assertive with $87.5 \%$ of the total sentences. This was far higher than the ORFPs for declarative acts which had a total of $34.4 \%$. This was followed by directives at $28 \%$, commisives at $18.8 \%$ while verdictives and expressives both had the least percentage at $15.6 \%$. It was then apparent from the ORFPs that the President used these acts in this manner to show a peculiar style of civilian politicians by being assertive in most of the sentences in his speeches (Table 3).

Table 3. Summary of the Tables $A-B$ (ORFPS)

\begin{tabular}{|l|c|c|}
\hline Speech Acts (Direct and Indirect) & Frequencies & Percentages \\
\hline Assertive & 28 & $87.5 \%$ \\
\hline Directive & 9 & $28 \%$ \\
\hline Expressive & 5 & $15.6 \%$ \\
\hline Verdictive & 5 & $15.6 \%$ \\
\hline Commisive & 6 & $18.8 \%$ \\
\hline Declarative & 11 & $34.4 \%$ \\
\hline
\end{tabular}

Total No of Acts:

64

The argument, in this paper, is that the macro speech act pattern, which is significant for meaning, is a product of epistemic, linguistic, social and physical contexts of the speeches. It is noteworthy that President Umaru Yar'Adua speeches are distinct from Military leaders' speeches. Military leaders make use 
of sentences that are highly verdictive and directive. It was observed that the verdictive acts were due to the performative nature of the two speeches. Indeed, they were basically meant for assessing, and directives were mainly for appealing, and not commanding which is usually the case with the Military leaders' speeches. ${ }^{32}$ The context of democratic government is thus differentiated from military government through macro speech patterns of the leaders. Hence, the speech acts in the research portrayed President Umaru Yar'Adua as a political leader.

The use of sentences that were assertive by the President demonstrated ingenuousness and directness. One of the expected qualities of politicians is diplomacy; they hide their intentions by saying one thing and doing the contrary. President Umaru Yar'Adua speeches made in the course of performing constitutional duties were direct and clear with speech acts that could be easily identified. He employed the declarative acts to exercise his legitimate power and authority reposed in has a democratically elected president. It was further discovered that democratic government places premium on people's interest. This fact was confirmed through the predominant speech acts in the analysis.

More interesting is the manner in which the various speech act features in the two speeches had the same percentages for assertives, commissives, expressives and declaratives, which were brought together in a cohesive relationship with one another to enhance meanings relevant to the context in the speeches. Despite the fact that the two speeches were presented on different occasions, they both share similar speech act patterns that were greatly influenced by the context of democratic government.

Indeed, participants, topic, setting, channel, code and message are the significant features of context. ${ }^{33}$ It is on this premise that pragmatists pay attention to role of context in language use. For instance, the time of delivery of Budget Speech required that the President's employment of commissives and declaratives than directives, verdictives or expressives. It was a period of economic challenges that called for utterances that would create perlocutionary acts of motivation, acceptance, understanding, acceptance and hopefulness.

\section{Conclusion}

Context is very important in interpretation and identification of speech acts in discourses. The linguistic context alone does not succinctly provide for meaning. The paper is in line with Nouraldeen's submission that successful

32. Moses Ayeomoni, "Lexical Analysis of Select Political Discourses of Nigeria's Military Heads of State" (Unpublished PhD dissertation, University of Ibadan, 2007).

33. Wale Osisanwo, Introduction to Discourse Analysis and Pragmatics (Lagos: FemolusFetop Publishers, 2003). 
communication is assured when the hearer properly interprets two contexts: the discourse context, i.e., the information contained in the words, and the physicalsocial context, i.e., the hearer's knowledge of the speaker, environment, and circumstances', which makes meaning a resultant effect of information from both words and context. ${ }^{34}$ Hence, the contribution of context to meaning is more pronounced in Pragmatics than any other linguistic or sub-linguistic field.

It is, therefore, obvious that the Speech Act theory is one of the reliable theories in pragmatics, which depends on context in interpreting and identifying acts. Its application to political discourses enhances a better understanding of political speeches and discourses. So, the theory of Speech Acts is strongly recommended for the analysis military leaders speeches in Nigeria. The study recommends a comparative analysis of performative and ceremonial political speeches of Presidents to investigate the speech act patterns.

\section{Bibliography}

Abuya, John. "A Pragma-stylistic Analysis of Inaugural Speech of President Goodluck Ebele Jonathan's Inaugural Speech." English Language Teaching 5, no. 11 (2012): 8-15.

Adeyanju, Dele. "Pragmatic Features of Political Speeches in English by Some Prominent Nigerian Leaders." Journal of Political Discourse Analysis 2, no. 2 (2009): 173-190.

Akinkurolere, Susan. "A Lexico-pragmatic Analysis of Inaugural Speeches of Speakers of State Houses of Assembly in Nigeria." Unpublished PhD Dissertation. Obafemi Awolowo University, 2016.

"A Pragmastylistic Analysis of Chinua Achebe's Arrow of God." Humanities and Social Sciences Review 3, no. 3 (2014): 363-370.

. "A Speech Act Analysis of Selected Political Speeches of President Umaru Musa Yar'Adua." Unpublished MA Dissertation. Obafemi Awolowo University, 2011.

Austin, John. How to Do Things with Words. Oxford: Oxford University Press, 1962. Awolaja, Abiodun. "A Pragmastylistic Analysis of Helon Habila's Waiting for an Angel and Measurement Time." Unpublished MA Dissertation. Obafemi Awolowo University, 2012.

Ayeomoni, Moses. "Lexical Analysis of Select Political Discourses of Nigeria's Military Heads of State." Unpublished PhD Dissertation. University of Ibadan, 2007.

Bach, Kent, and Robert Harnish. Linguistic Communication and Speech Acts. Cambridge: M.I.T Press, 1979.

34. Nouraldeen, "Meaning and Context-Three Different Perspectives. 
Bloor, Thomas, and Meriel Bloor. The Functional Analysis of English: A Hallidayan Approach. London: Arnold, 2004.

Halliday, Micheal. "Language Structure and Language Function." In New Horizons in Linguistics, edited by John Lyons, 142-165. USA: Penguin Books, 1970.

Illes, Eva. "The Definition of Context and its Implications for Language Teaching." Doctoral Dissertation-PhD. Institute of Education, University of London, 2001.

Loukasa, Soile. "The Use of Context in Pragmatic Language Comprehension in Normally Developing Children and Children with Asperger Syndrome/ High-Functioning Autism: An Application of Relevance Theory." University Dissertation. Faculty of Humanities, University of Oulu, 2007.

Lyons, John. Semantics (Volume 2). Cambridge: Cambridge University Press, 1977.

Mahmud, Olayemi. "A Stylistic Study of the Language of Television Advertisement in Nigeria." Unpublished MA Dissertation. Adekunle Ajasin University, 2004.

Mey, Jacob. Pragmatics: An Introduction. Oxford: Blackwell Publishing, 2006.

Morris, Charles. Foundations of the Theory of Signs. Chicago: University of Chicago Press, 1938.

Nouraldeen, Abdullah. "Meaning and Context-Three Different Perspectives." British Journal of English Linguistics 3, no. 2 (2015): 13-17.

Opeibi, Babatunde. Discourse, Politics and the 1993 Presidential Election Campaigns in Nigeria. Lagos: Nouvelle Communications Limited, 2009.

Osisanwo, Wale. Introduction to Discourse Analysis and Pragmatics. Lagos: FemolusFetop Publishers, 2003.

Searle, John. Speech Acts. Cambridge: Cambridge University Press, 1969.

Thomas, Jenny. Meaning in Interaction: An Introduction to Pragmatics. New York: Longman, 1995.

Yule, George. Pragmatics. Oxford: Oxford University Press, 1996.

_. The Study of Language. Cambridge: Cambridge University Press, 1985. 
